\title{
Reproductive morphology and phenological aspects of one morphological variant of Hypnea pseudomusciformis (Gigartinales, Rhodophyta)
}

\author{
Priscila Barreto de Jesus ${ }^{1 *}$ (1), Edilene Maria dos Santos Pestana ${ }^{1,2}$ (1), Helen Michelle de Jesus Affe ${ }^{2}$ (D), \\ Diogo Souza Bezerra Rocha ${ }^{3}$ (D), Taiara Aguiar Caires ${ }^{1,2}$ (D), José Marcos de Castro Nunes ${ }^{1,2}$ (1) \\ and Alessandra Selbach Schnadelbach ${ }^{1,4}$ (i)
}

Received: July 13, 2018

Accepted: October 10, 2018

\begin{abstract}
Hypnea pseudomusciformis was recently described from South America, and has three morphological variants: "musciformis", "nigrescens", and "valentiae". Information on the biology of these variants may help to explain this species' wide morphological variation despite the absence of genetic divergence among variants. More morphological and ecological data has accumulated on the "musciformis" variant occurring on the Brazilian coast than for the others. In this study, we described the reproductive morphology of a tropical "nigrescens" population and investigated its phenology to provide crucial biological information about this taxon, and perhaps also assist in answering questions about the systematics of $H$. pseudomusciformis variants. The population analyzed showed no significant fluctuations in its total biomass throughout the year. All reproductive stages were frequently recorded during this study, which contributes greatly to our knowledge of the reproductive morphology of the "nigrescens" variant. Phenological variations were correlated with environment variables, such as air and sea-surface temperatures, insolation, precipitation, and humidity. Male gametophytes were frequently present, which has never been reported for the "musciformis" variant. We showed that, despite being members of the same genetic species, the "nigrescens" and "musciformis" morphological variants exhibit remarkable differences in their ecology and biology.
\end{abstract}

Keywords: biomass, Cystocloniaceae, ecology, Hypnea musciformis complex, reproduction, systematics

\section{Introduction}

Species of the red algal genus Hypnea have the polysaccharide kappa-carrageenan as the main constituent of their cell walls, which is widely used in the food, cosmetic, and pharmacological industries (Knutsen et al. 1995; Masuda et al. 1997; Reis et al. 2008; Najam et al. 2010; Caires et al. 2013a). Carrageenan is used in the production of candy, tungsten filament coating, soups and sauces, creams, soaps, and insecticides, and also in the photographic, dairy, textile, and paper industries. Previous studies have shown that some Hypnea species have fungicidal (Melo et al. 1997) and anti-inflammatory

1 Programa de Pós-graduação em Botânica, Departamento de Ciências Biológicas, Universidade Estadual de Feira de Santana, 44031-460, Feira de Santana, BA, Brazil

2 Laboratório de Algas Marinhas, Departamento de Botânica, Instituto de Biologia, Universidade Federal da Bahia, 40170-115, Salvador, BA, Brazil 3 Instituto de Pesquisa Jardim Botânico do Rio de Janeiro, 22460-030, Rio de Janeiro, RJ, Brazil

4 Laboratório de Genética e Evolução de Plantas, Departamento de Biologia Geral, Instituto de Biologia, Universidade Federal da Bahia, 40170-115, Salvador, BA, Brazil

* Corresponding author: priscilla_b.j@hotmail.com 
(Bitencourt et al. 2008) properties, and can also be used as fertilizers in rice plantations (Selvan \& Kannan 1990).

Hypnea pseudomusciformis is a species recently described from the South Atlantic Ocean, which is closely related to the previously described species $H$. musciformis from other parts of the world (Nauer et al. 2015). Based on molecular data, Nauer et al. (2015) determined that the species $H$. pseudomusciformis encompasses three morphological variants that were previously described from Brazil as distinct taxa, specifically $H$. musciformis, $H$. nigrescens, and $H$. valentiae. For decades, Brazilian authors (Schenkman 1986; Nunes 2005; Jesus et al. 2013b; 2014; Nauer et al. 2015) distinguished these taxa based on differences in their life habits and gross morphology as follows: the "musciformis" variant has abundant tendrils at the ends of its branches and branchlets; the "nigrescens" is easily recognized in the field by its epilithic habit, green or blackish color, and the resemblance of the appearance of their branches the bristles of a brush; and the "valentiae" has delicate thalli, reaches the greatest heights among all three variants, and has a more open and loosely arranged pattern of branching.

Research conducted on Brazilian Hypnea species has demonstrated that, in addition to the marked differences in their morphological traits, the morphological variants of $H$. pseudomusciformis also exhibit differences in their life habits, habitats, and reproduction (Schenkman 1986; Nunes 2005; Jesus 2012; 2016; Jesus et al. 2013b; 2014) that do not seem to be related to genetic differentiation among them (Nauer et al. 2015). Specimens with the "musciformis" morphology mainly forms sublittoral epiphytic populations, while the "nigrescens" variant usually grows attached to rocks in the middle intertidal zone on rocky shores with strong wave inputs, and the "valentiae" generally occurs in areas protected from direct wave action, such as in tidal pools. These variants rarely occur in sympatry and, when this occurs, one variety usually forms larger populations while the other(s) remain restricted to a few individuals each (personal observation).

Schenkman (1986) observed that morphological differences among these three variants are maintained in culture, demonstrating that these differences are determined by more than just different environments. Recently, Nauer et al. (2017b) carried out in vitro breeding tests between "nigrescens" and "musciformis" variants, which confirmed that these taxa belong to the same species according to the biological species concept (Wright 1940; Mayr 1942; Dobzhansky 1950). There is great disparity in the extent and types of information accumulated concerning different aspects of the biology and ecology of these morphological variants along the Brazilian coast. While many different aspects of the morphology, ecology, economical proprieties, and physiology of the "musciformis" variant have been well-studied (Schenkman 1986; 1989; Selvan \& Kannan
1990; Knutsen et al. 1995; Wallner et al. 1992; Masuda et al. 1997; Melo et al. 1997; Reis \& Yoneshigue-Valentin 2000; Nunes 2005; Bitencourt et al. 2008; Reis et al. 2008; Najam et al. 2010; Jesus 2012; 2016; Caires et al. 2013a; b; Jesus et al. 2013a; b; 2014; Nauer et al. 2015; among others), little or none information exists on the biology of the other variants of this species. It is crucial that essential biological information about these taxa be obtained to assist in the resolution of their intraspecific relationships.

Ecological traits are generally used to complement the descriptions of algal species; however, evaluations of variations in phenology are not commonly used at taxonomic scale in phycological studies. Espinoza-Avalos (2005) defined the phenology of macroalgae as the timing of recurring biological events, as well as the underlying causes of their timing by abiotic and biotic factors. Several studies have been conducted to describe the phenology and reproductive biology of Hypnea species (Mshigeni 1976a; b; c; Rao 1977; Rangaiah \& Rao 1983; Schenkman 1989; Wallner et al. 1992; Reis \& Yoneshigue-Valentin 2000; Reis et al. 2008; Smith et al. 2002; Kong \& Ang Jr. 2004; Mouradi et al. 2008; Shameel et al. 2012; Caires et al. 2013b), and most have claimed that their phenology is strongly influenced by environmental factors. At the same time, Forrest \& MillerRushing (2010) drew attention to the fact that phenology is an important adaptive trait resulting from a complex interplay among an organism's genes and several external environmental factors.

Thus far, phenological analyses of Hypnea pseudomusciformis along the Brazilian coast were only performed on the "musciformis" variant, and these studies observed the prevalence of tetrasporophytes and absence of male gametophytes throughout the year in the region (Schenkman 1989; Wallner et al. 1992; Reis \& Yoneshigue-Valentin 2000; Caires et al. 2013b). Because of this, the reproductive morphology of the gametophytes of $H$. pseudomusciformis is poorly known, especially for male specimens, which may lead to misinterpretations in phenological studies. "valentiae" has a restricted distribution and forms small populations (Schenkman 1986; Jesus 2012; Nauer et al. 2015), making it difficult to assess its phenology. Conversely, "nigrescens" seems to be widely distributed along the Brazilian coast (Schenkman 1986; Nunes 2005; Guimarães 2006; Lyra et al. 2007; Jesus 2012; Jesus et al. 2013b; Nauer et al. 2015). In Brazil's Bahia state, "nigrescens" forms large populations on the north coast, although these occur on beaches that are very distant from each other.

In the present study, we described the reproductive morphology of the "nigrescens" variant of $H$. pseudomusciformis and evaluated its biomass and phenology in a tropical area of the Brazilian coast, including correlating variations in its phenology with changes in abiotic factors. This will provide essential biological and 
ecological information about this taxon, which can be used to help address systematic questions within the species H. pseudomusciformis.

\section{Materials and methods}

Study site

The present study was carried out on a rocky shore of Emissário Beach (1244'25.70”S 388'58.97”W), located at Arembepe, on the north coast of Bahia State, Brazil (Fig. 1). The shore here is fragmented, directly exposed to strong hydrodynamic forces, and mainly occupied by sessile mollusks and calcareous algae. This site was chosen because of the presence there of uncommonly large beds of the "nigrescens" variant of the red macroalga Hypnea pseudomusciformis Nauer, Cassano et M.C. Oliveira. According to Leão et al. (2010), the region containing this site has a tropical climate, with precipitation of as much as $1300 \mathrm{~mm} \mathrm{y}^{-1}$ in its northern portion. Average air temperatures range from $23^{\circ} \mathrm{C}$ during the winter to $28^{\circ} \mathrm{C}$ in the summer, and surface temperatures of the seawater vary from approximately $24^{\circ} \mathrm{C}$ in winter to $28^{\circ} \mathrm{C}$ in summer. Spring tides at the site can reach tidal ranges of up to $3.0 \mathrm{~m}$.

\section{Sampling}

Samples were collected on a monthly basis from August 2013 to July 2014 using a destructive sampling methodology (Wreede 1985). Samples were collected in the intertidal zone during spring low tides $(0.0 \mathrm{~m}$ to $0.3 \mathrm{~m})$, and always during the mornings within the first fortnight of each month. For quantitative inferences (phenological and biomass estimates), three 20-m transects were established parallel to the shoreline. In each transect, five random points were selected at which $0.04 \mathrm{~m}^{2}$ quadrats were examined. Each quadrat was considered as one sample, with a total of 180 samples analyzed (15 samples per collection). All specimens contained in the quadrats were collected. For analyses of frond lengths, individuals were arbitrarily collected from the area around each transect in each month, with approximately 20 specimens sampled per transect per month for a total of 250 specimens. All specimens were collected with the aid of a metal spatula, and transferred to the laboratory in plastic bags containing seawater.

\section{Reproductive morphology}

Samples were fixed in $4 \%$ formalin and analyzed under a stereomicroscope (Leica Zoom ${ }^{\circledR}$ 2000) to remove algae epiphytes and sediment, and to identify the reproductive stages of the specimens in each sample. Detailed morphological analyses of each reproductive stage were conducted following Jesus (2012). Histological sections were made by hand with a razor blade, and reproductive structures were stained with $5 \%$ aniline blue solution. Identification of structures was done under a stereomicroscope and a photonic microscope (Olympus ${ }^{\circledR} \mathrm{CBA}$ ) with an attached measuring ocular lens. Photomicrographs of reproductive structures were taken with the aid of an image capture program (QCapture Pro) and a digital camera (QImaging GO-3) attached to the photomicroscope (Olympus trinocular CX31RTS5 ${ }^{\circledR}$.

The following features of the reproductive morphology of the "nigrescens" variant were observed: (1) general appearance of the gametophyte/tetrasporophyte; (2) position of cystocarps on the axis, branches, and branchlets; (3) form and diameter of cystocarps; (4) presence of ostiole in cystocarps; (5) shape and diameter of carposporangia; (6) position of the spermatangial/tetrasporangial sori on the axis, branches and branchlets; (7) form and diameter of the spermatangial/tetrasporangial sori; (8) arrangement of spermatangia/tetrasporangia on fertile branchlets; and (9) shape and size of spermatangia/tetrasporangia.

\section{Biomass and phenology}

All collected specimens were separated into tetrasporophytes, female gametophytes (with cystocarps), male gametophytes (Fig. 2A-L), and non-reproductive (vegetative or infertile) fronds. Clumps of each specimen occur separately with stolon-like and erect branches arising a basal portion strongly anastomosed. After making phenological inferences, the seaweeds were dried in a drying oven (Fanem ${ }^{\circledR}$, São Paulo, Brazil) at $60^{\circ} \mathrm{C}$ for $48 \mathrm{~h}$ or until a constant weight was reached. Dry biomass data were then expressed as means standard deviation $(S D)\left(\mathrm{g} \mathrm{m}^{-2}\right)$ or as percentages of total dry biomass. The lengths of fronds were measured from the base to the tip of each clump (i.e. specimen). After morphometric measurements were completed, these samples were herborized according to Nunes (2010) and deposited in the Herbarium Alexandre Leal Costa Bahia (ALCB) at Universidade Federal da Bahia (UFBA), with record numbers 114410 to 114475 .

\section{Abiotic factors}

Daily means of data collected at 0h00min (12:00 am) for abiotic factors potentially affecting phenology, such as precipitation, humidity, monthly insolation, and air temperature, were calculated for use in analyses. These data were obtained from the National Meteorological Institute (INMET, http://www.inmet.gov.br/portal/index. php?r=bdmep/bdmep, accessed May 2018). Sea-surface temperature and salinity were measured in situ at the time of sampling as close as possible to the collection area using an electronic thermometer (model SH-102, JProlab, Parana, Brazil) and a portable refractometer (model 103, Biobrix ${ }^{\circledR}$, São Paulo, Brazil), respectively. 
Priscila Barreto de Jesus, Edilene Maria dos Santos Pestana,

Helen Michelle de Jesus Affe, et al.


Depth (m)

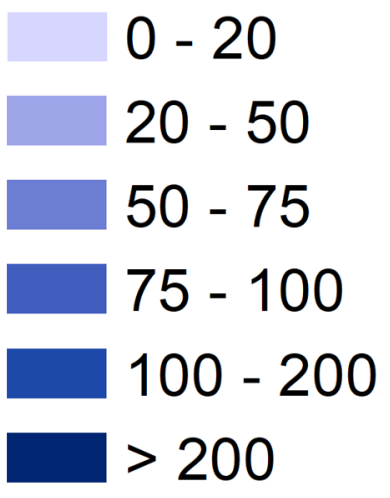

Figure 1. Map showing the study location at Emissário Beach, Bahia State, Brazil. 


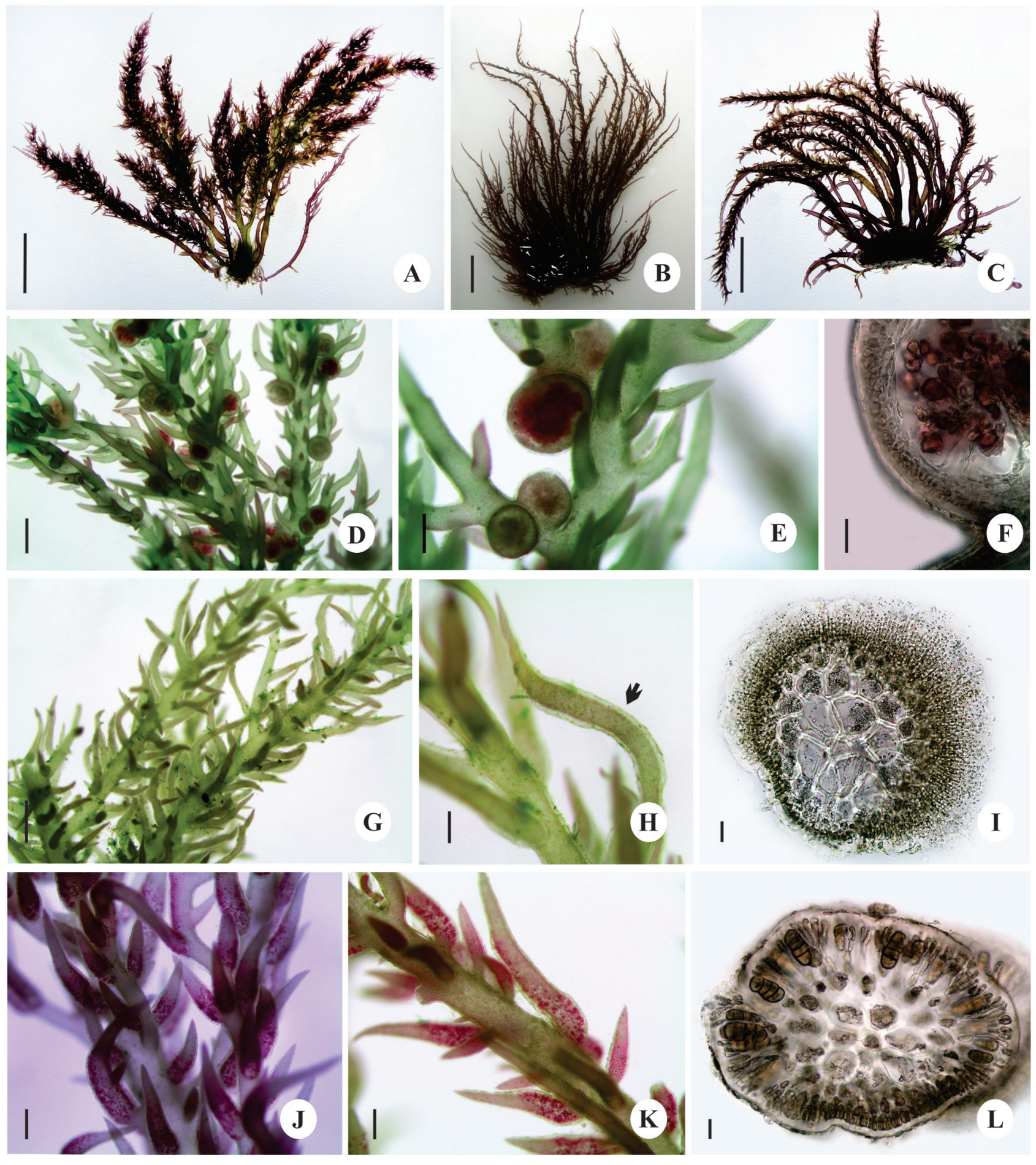

Figure 2. General appearance and reproductive morphology of the "nigrescens" morphological variant of Hypnea pseudomusciformis. A. General appearance of a female gametophyte plant. B. General appearance of a male gametophyte plant. C. General appearance of a tetrasporophyte. D. Cystocarps on branches and branchlets of a female plant. E. Cystocarps in detail. F. Longitudinal section through a mature cystocarp. G. Spermatangial sori in branchlets on a male plant. H. Magnified image of a spermatangial sorus (arrow). I. Cross-section of a branchlet incompletely surrounded by spermatangia. J. Tetrasporangial sori on branchlets. K. Magnified image of tetrasporangial sori. L. Cross-section of a branchlet incompletely surrounded by tetrasporangia. Scale bars: A, B and C = $1 \mathrm{~cm} ; \mathrm{D}=$ $500 \mu \mathrm{m} ; \mathrm{E}=600 \mu \mathrm{m} ; \mathrm{F}=40 \mu \mathrm{m} ; \mathrm{G}=1 \mathrm{~cm} ; \mathrm{H}=200 \mu \mathrm{m} ; \mathrm{I}=100 \mu \mathrm{m} ; \mathrm{J}=400 \mu \mathrm{m} ; \mathrm{K}=300 \mu \mathrm{m} ; \mathrm{L}=100 \mu \mathrm{m}$. 


\section{Priscila Barreto de Jesus, Edilene Maria dos Santos Pestana, Helen Michelle de Jesus Affe, et al.}

\section{Statistical analyses}

Data for dry biomass, phenology, and frond length were tested for normality of residuals and homoscedasticity with the Shapiro-Wilk and Levene's tests, respectively. The data were nonparametric; therefore, were normalized by logarithmization $[\log (x+1)]$ and square root for biomass and length of fronds, respectively. We used a two-way ANOVA to verify if there were significant differences in the biomass and lengths of fronds, considering the fixed factors months and stages, in the study period. A Tukey's test was applied a posteriori to verify which periods showed significant differences throughout the study. We also performed Spearman's correlation tests to determine the possible relationships of the biomass and lengths of thalli with the environmental variables analyzed. For all analyses, the significance level was set at $p \leq 0.05$. All statistical analyses were carried out in an $\mathrm{R}$ software environment (R Core Team 2018).

\section{Results}

\section{Reproductive morphology}

The "nigrescens" variant was observed in this study to occur as epilithic thalli that are strongly attached to the substrate and form clumps. The thallus is erect, cartilaginous, green to greenish black, and measures $2.5-8 \mathrm{~cm}$ in height. Tufts are formed with a portion of the rhizoidal branches strongly adhered to the substrate, from which stolon-like and erect branches originate. Usually the longer axes are inserted at the central portion of the tuft, resembling the bristles of a brush. The apices of branches and branchlets are usually curved but may be straight. Subulate branchlets (each with a broad base and tapered apex) are irregularly arranged from 0.5 to $1.0 \mathrm{~cm}$ above the base, and are typically naked. The median and apical portions of the thallus are intensely and irregularly branched, with a tendency to spiral.
The appearance of the tetrasporic, female and male plants are shown in Figure 2A-C. Female plants (Fig. 2A) are more robust and display more intense branching than male (Fig. 2B) and tetrasporic (Fig. 2C) plants. Cystocarps are produced from the median to the apex of the axis and branches, occurring singly or in aggregations (Fig. 2D); they are globose (Fig. 2E), 357-599 $\mu \mathrm{m}$ in length and 393-601 $\mu \mathrm{m}$ in diameter, each have a thick pericarp and does not display evident ostioles (Fig. 2F). Carposporangia are ovate, 17-31 $\mu \mathrm{m}$ in diameter, and dispersed within the cystocarp. Spermatangial sori are produced from the median to the apex of the axis and branches (Fig. 2G), are more swollen and lighter in color than the sterile branchlets. Spermatangia incompletely surround the basal and median portion of the branchlets and make them curve and resemble a cloud around each branchlet (Fig. 2H); they are spherical, 4.1-6.3 $\mu \mathrm{m}$ in diameter, and arranged in a concatenated manner in the cortical region (Fig. 2I). Tetrasporangial sori are formed from the median to the apex of the axis and branches (Fig. 2J), and are more swollen and darkly pigmented than sterile and spermatangial areas (Fig. 2K). Zonate tetrasporangia are 36-167 $\mu \mathrm{m}$ in length and 15-74 $\mu \mathrm{m}$ in diameter (Fig. 2L), typically incompletely surround the basal and median portion of the branchlets, and make the branchlets curve.

\section{Environment data}

The abiotic data analyzed in this study showed values typical of a tropical region (Tab. 1). Mean air temperatures ranged from $23^{\circ} \mathrm{C}$ in July 2014 to $26.4^{\circ} \mathrm{C}$ in April 2014, and the total monthly insolation ranged from $147 \mathrm{~h}$ in August 2013 to $230 \mathrm{~h}$ in April 2014. The accumulated precipitation ranged from $41 \mathrm{~mm}$ in December 2013 to $167 \mathrm{~mm}$ in June 2014 , whereas the average humidity raged from $81.4 \%$ to $88 \%$ in April and June 2014, respectively. Sea-surface temperatures varied by a maximum range of $4^{\circ} \mathrm{C}\left(26\right.$ to $30^{\circ} \mathrm{C}$; $27 \pm 1.4^{\circ} \mathrm{C}$ ), while the maximum variation in salinity was 9 (31 to $40 ; 36 \pm 2.3$ ).

Table 1. Environmental variables recorded on the coast of Bahia State, Brazil between August/2013 and July/2014.

\begin{tabular}{|c|c|c|c|c|c|c|}
\hline Month & $\begin{array}{l}\text { Accumulated precipitation } \\
\qquad(\mathrm{mm})^{*}\end{array}$ & $\begin{array}{l}\text { Mean monthly humidity } \\
(\%)^{*}\end{array}$ & $\begin{array}{l}\text { Air temperature } \\
\left({ }^{\circ} \mathrm{C}\right)^{*}\end{array}$ & $\begin{array}{c}\text { Total insolation } \\
\text { (h)* }\end{array}$ & $\begin{array}{l}\text { Sea surface temperature } \\
\qquad\left({ }^{\circ} \mathrm{C}\right)^{* *}\end{array}$ & Salinity** \\
\hline August/2013 & 100 & 84.8 & 27 & 186.1 & 30 & 37 \\
\hline September/2013 & 81.8 & 83.8 & 27.4 & 191.3 & 26 & 36 \\
\hline October/2013 & 79.6 & 82.4 & 28.2 & 205.1 & 26.6 & 36 \\
\hline November/2013 & 85.4 & 83.1 & 29 & 196.3 & 26 & 36 \\
\hline December/2013 & 41.0 & 82.8 & 29.3 & 167.5 & 26.9 & 35 \\
\hline January/2014 & 41.1 & 81.6 & 29.5 & 204.9 & 27.2 & 31 \\
\hline February/2014 & 42.2 & 83.8 & 29.4 & 188.3 & 27.7 & 33 \\
\hline March/2014 & 91.0 & 82.1 & 30 & 228.3 & 27.9 & 40 \\
\hline April/2014 & 47.7 & 83.8 & 29.2 & 200.7 & 26 & 37 \\
\hline May/2014 & 85.6 & 87.2 & 27.5 & 153.1 & 27.4 & 36 \\
\hline June/2014 & 166.8 & 87.2 & 26.7 & 148.9 & 28.9 & 34 \\
\hline July/2014 & 96.2 & 86 & 26.4 & 142.5 & 29.6 & 37 \\
\hline
\end{tabular}

${ }^{*}$ Font: National Institute of Meteorology (INMET); ${ }^{* *}$ Measured in the study area. 


\section{Biomass, phenology, and frond length analyses}

The "nigrescens" variant was present on Emissário Beach in all the months in which samples were collected in this study. The total monthly biomass of this alga ranged from 0.14 to $0.50 \mathrm{~g} \mathrm{~m}^{-2}$, with no significant differences ( $p$ $=0.15$ ) occurring among any of the months throughout the collection period (Tab. 2, Fig. 3). Tetrasporophytes and female gametophytes were found throughout the entire sampling period. Male gametophytes were absent in August 2013, while vegetative fronds were very rare in general, being observed only in August 2013. The biomass of male gametophytes throughout the year was low, and therefore the biomass of male gametophytes did not differ significantly among the months studied (Tab. 2). The biomass of tetrasporophytes, however, varied among the months studied. Specifically, the biomass of tetrasporophytes measured in June 2014 was significantly lower than that measured in October $2013(p=0.02)$ and November 2013 ( $p=0.01$ ), and significantly higher than that observed in April 2014 ( $p=0.004)$. The biomass of female gametophytes in April 2014 was significantly higher than that measured in August 2013 ( $p=0.02$ ). The biomass of tetrasporophytes was significantly different from those of vegetative $(p=0.02)$, cystocarpic $(p<0.01)$, and male fronds $(p<0.01)$ (Tab. 2).

Table 2. Summary of two-way ANOVA results for the biomass and lengths of fronds of the "nigrescens" population on Emissário Beach, Bahia State, Brazil among the months studied.

\begin{tabular}{|c|c|c|}
\hline Biomass & F value & $\boldsymbol{p}$ \\
\hline Months & 2.652 & 0.15 \\
\hline Stages & 84.464 & 0.001 \\
\hline Months:Stages & 0.886 & 0.003 \\
\hline Tetrasporophytes & $0.21-0.93(0.58 \pm 0.21)$ & $\mathrm{a}$ \\
\hline Female gametophyte & $0.07-0.23(0.13 \pm 0.07)$ & $\mathrm{b}$ \\
\hline Male & $0-0.16(0.06 \pm 0.04)$ & $\mathrm{b}$ \\
\hline Size of the thallus & $\mathbf{F}$ value & $\boldsymbol{p}$ \\
\hline Months & 13.936 & 0.001 \\
\hline Stages & 0.768 & 0.513 \\
\hline Months:Stages & 1.061 & 0.392 \\
\hline Tetrasporophytes & $3.41-7(5.44 \pm 0.99)$ & $\mathrm{a}$ \\
\hline Female gametophyte & $3.89-6.91(5.34 \pm 0.8)$ & $\mathrm{a}$ \\
\hline Male gametophyte & $4-6.5(5.16 \pm 0.96)$ & $\mathrm{a}$ \\
\hline
\end{tabular}

$\max =$ maximum value; $\min =$ minimum value $S \mathrm{SD}=$ standard deviation; $\mathrm{p}=$ probability

The percentage of the sampled population's biomass made up of tetrasporophytes, female and male gametophytes, and non-reproductive fronds in each month are shown in Figure 4. Tetrasporophytic fronds accounted for more than half of the total dry biomass in all studied months (74.63\%), with female and male gametophytes representing the remaining $17.10 \%$ and $6.80 \%$ of the biomass, respectively. Considering the entire sampling period, vegetative fronds were very rare (1.47\%), occurring only during August 2013. We observed the highest frequency of tetrasporophytes in November 2013 (88.79\%) and the lowest in January 2014 (62.82 \%), whereas the occurrence of cystocarpic fronds was lower in October 2013 (7.20\%) and higher in January 2014 (29.85\%). April 2014 was the month with the highest frequency of male fronds (13.95\%).

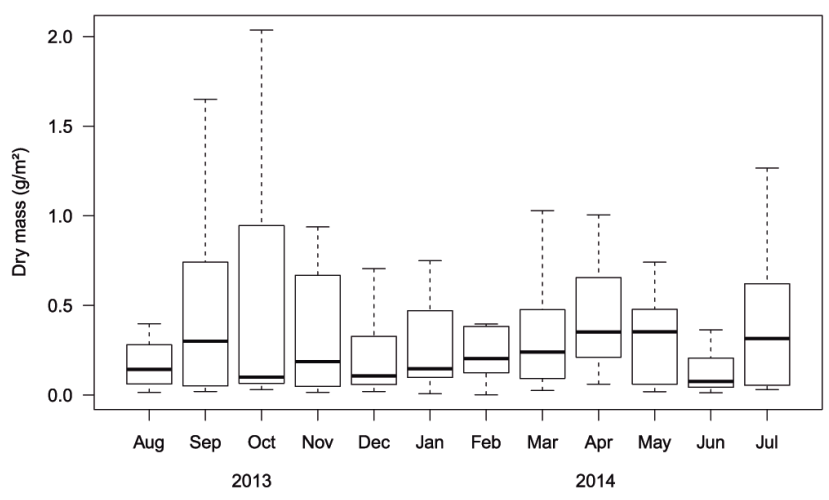

Figure 3. Total biomass (dry mass) of the "nigrescens" variant at Emissário Beach during the sampling period. Vertical lines = range of measurements; central boxes = inter-quartile ranges; central horizontal lines $=$ median values

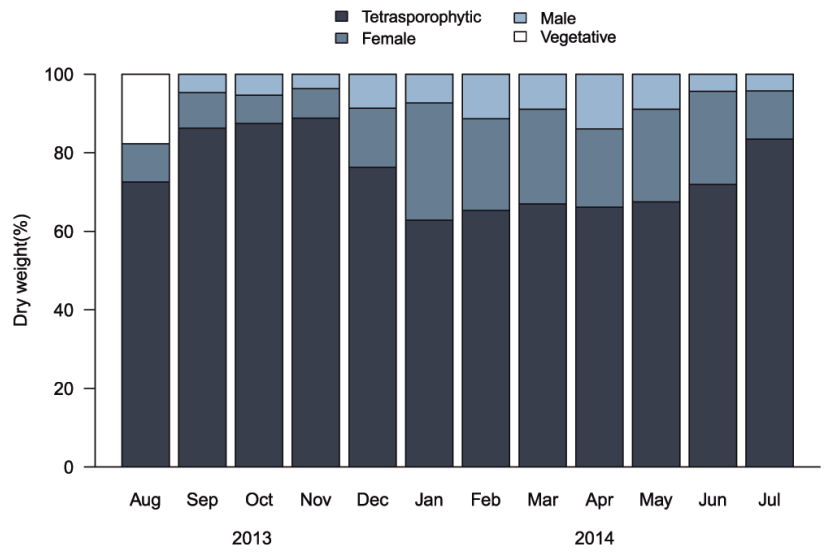

Figure 4. Percentages of biomass (dry mass) made up by each reproductive stage (vegetative, tetrasporophytic, and female and male gametophytes) of the "nigrescens" variant.

The sizes of thalli ranged from $3.64 \mathrm{~cm}$ to $6.77 \mathrm{~cm}$ (Tab. 2). Significant differences $(p<0.001)$ in frond lengths were detected throughout the sampling period. The smallest fronds were recorded in June 2014 (Tab. 2, Fig. 5). With respect to the mean thallus lengths of the different reproductive stages (Fig. 6), tetrasporophytes and female gametophytes reached their maxima in October 2013 and minima in June 2014, while male gametophytes reached their greatest lengths during February 2014 and their shortest lengths in June 2014. 


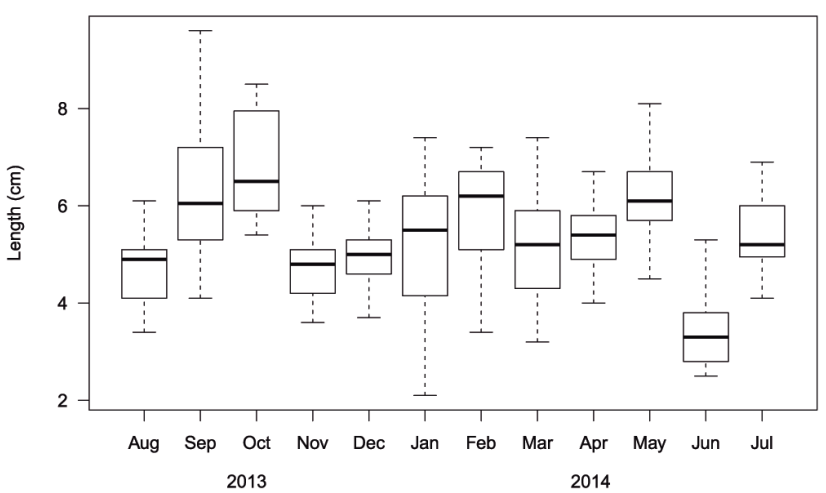

Figure 5. Variation in mean frond lengths of the "nigrescens" variant during the sampling period. Vertical lines = range of measurements; central boxes = inter-quartile ranges; central horizontal lines $=$ median values .

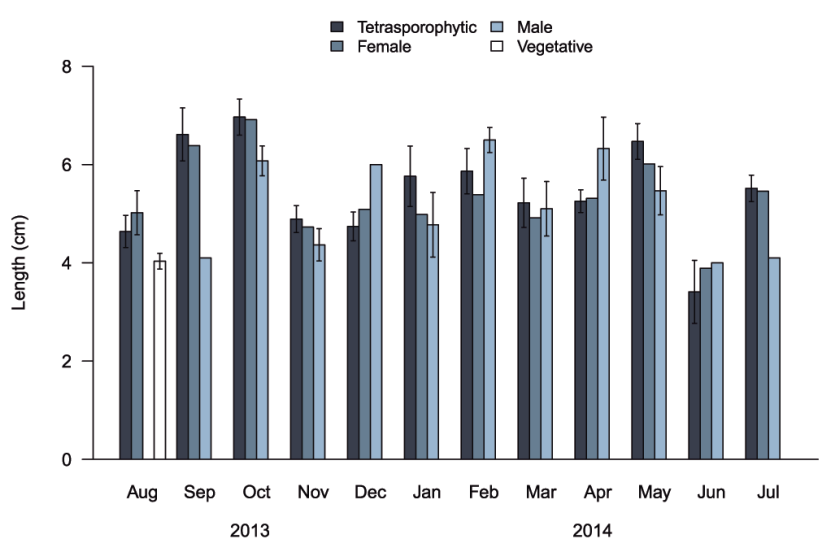

Figure 6. Mean thallus lengths for the different stages (vegetative, tetrasporophytic, and female and male gametophytes) of the "nigrescens" variant. Error bars represent standard errors.

Significant correlations between the biomass and sizes of fronds of the "nigrescens" variant and the environmental variables recorded during the study are shown in Table 3. Total biomass was negatively correlated with sea-surface temperature. A negative correlation was observed between the biomass of tetrasporophytes and sea-surface temperature. The biomasses of male and female gametophytes were positively correlated with air temperature and negatively correlated with relative humidity. Male gametophyte biomass was positively correlated with monthly insolation. Regarding frond lengths, only those of male gametophytes had any significant correlations with the environmental variables recorded; these were positively correlated with air temperature and monthly insolation, and negatively correlated with precipitation and relative humidity.

\section{Discussion}

In this study, we provided detailed information that can facilitate the detection of the occurrence of male gametophytes of the "nigrescens" morphological variant of Hypnea pseudomusciformis, which can be difficult to find and identify, especially in the field. A distinctive feature of this variant is that the tetrasporangia and spermatangia typically occur only on one side of the branchlets, causing a slight curvature in branchlets. The morphology of the gametophytes of $H$. pseudomusciformis is usually poorly described, with only their external appearance being emphasized. Schenkman (1986) assigned the difficulty in detecting male specimens, in part, to the absence of descriptions of these stages and their structures in bibliographic references. Contrary to this, recent taxonomic studies (Jesus et al. 2013a; b; 2014; 2015; 2016) have demonstrated the occurrence of male gametophytes in several Hypnea species, confirming that this reproductive stage is much more common than was previously reported.

The total biomass of "nigrescens" did not undergo significant fluctuations throughout the year, which differed from observations reported for the "musciformis" variant on the Brazilian coast (Schenkman 1989; Wallner et al. 1992; Reis \& Yoneshigue-Valentin 1998; Faccini \& Berchez 2000; Caires et al. 2013a). Reis \& Yoneshigue-Valentin (1998) related these fluctuations in the biomass of "musciformis" to environmental factors, although they also pointed out the absence of such a seasonal pattern in populations from Rio de Janeiro State. On the other hand, data from previous published studies carried out on the coast of Bahia state showed conflicting patterns: Wallner et al. (1992) reported decreasing biomass during the summer, whereas Caires et al. (2013a) recorded the highest biomass values during this season. We observed a decline in the total biomass of "nigrescens" plants in the winter (June 2014), when the highest accumulated precipitation was recorded; however, no statistically significant differences among months were evident in the present study.

Table 3. Significant correlations between biomass and frond lengths of the "nigrescens" variant and various environmental variables measured at Emissário Beach, Bahia State, Brazil, from August 2013 to July 2014.

\begin{tabular}{|c|c|c|c|}
\hline & Environmental variables & $r$ value & $p$ value \\
\hline Biomass & & & \\
\hline Total & Sea surface temperature & -0.69 & 0.01 \\
\hline Tetrasporophyte & Sea surface temperature & -0.65 & 0.02 \\
\hline Female gametophyte & Air temperature & 0.76 & 0.004 \\
\hline & Relative humidity & -0.69 & 0.01 \\
\hline Male gametophyte & Air temperature & 0.78 & 0.004 \\
\hline & Insolation & 0.67 & 0.02 \\
\hline Total frond length & Relative humidity & -0.76 & 0.01 \\
\hline Male gametophyte & Air temperature & 0.70 & 0.01 \\
\hline & Insolation & 0.82 & 0.002 \\
\hline & Precipitation & -0.65 & 0.03 \\
\hline & Relative humidity & -0.84 & 0.001 \\
\hline
\end{tabular}

$\mathrm{r}=$ Spearman's rho correlation coefficient; $p=$ probability 


\section{Reproductive morphology and phenological aspects of one morphological variant of Hypnea pseudomusciformis (Gigartinales, Rhodophyta)}

Regarding the reproductive phenology of the "nigrescens" population studied herein, the highest proportion of the total biomass was observed to be made up by tetrasporophytes, followed by female and male gametophytes, and then by vegetative fronds. According to Cecere et al. (2000), the dominance of populations by the tetrasporophyte appears to be very common in red algae, and this was also previously reported in natural populations of Hypnea species (Rangaiah \& Rao 1983; Schenkman 1989; Wallner et al. 1992; Faccini \& Berchez 2000; Reis \& Yoneshigue-Valentin 2000; Kong \& Ang Jr. 2004; Mouradi et al. 2008; Caires et al. 2013b). Two main hypotheses can explain the predominant occurrence of the tetrasporophytic phase in Hypnea populations: (1) tetrasporophytes may produce more upright thalli per plant and are thus more robust under stressful conditions (Mathieson 1989); or (2) populations maintain themselves mainly by vegetative reproduction (Schenkman 1989). The latter hypothesis is possibly the most plausible for the studied population because it developed under conditions of strong and frequent water motion, thereby resulting in fragmentation of the fronds and their regeneration as diploid thalli.

Female and male gametophytes of the "nigrescens" variant were frequently found throughout the sampling period. This observation contradicts those of most previous studies of the "musciformis" variant in Brazil (Schenkman 1989; Wallner et al. 1992; Reis \& Yoneshigue-Valentin 2000; Caires et al. 2013b), and those of other Hypnea species throughout the world (Rao 1977; Rangaiah \& Rao 1983; Kong \& Ang Jr. 2004; Mouradi et al. 2008), in which gametophytes were reported to be rare or absent. Already the vegetative fronds were found only in August 2013, despite representing a considerable proportion $(\sim 20 \%)$ of the total biomass collected during this month. Non-fertile specimens of other Hypnea species have been regularly reported, and their presence is attributed to increases in conditions stressful for plant growth caused by abiotic factors (Reis \& Yoneshigue-Valentin 2000). The rare incidence of vegetative specimens in the present study, as well as the frequency of female and male gametophytes, could be an indication that this population grows in a favorable environment despite experiencing high hydrodynamic activity, and the algae therein are thereby able to complete their full life cycle and reproduce sexually.

The total biomass of the studied "nigrescens" population, as well as the biomass of tetrasporophytes, was significantly and negatively correlated with sea-surface temperature. This was also observed for the "musciformis" variant in southeastern and northeastern Brazil (Schenkman 1989; Wallner et al. 1992), and in other tropical and subtropical populations of Hypnea musciformis in several locations across the world (Rao 1970; Guist Jr et al. 1982; Kong \& Ang Jr. 2004). Mshigeni (1977) inferred that the highlight intensity and high-temperature conditions of the summer were among the most important factors responsible for the reduction of Hypnea populations they observed during this season. Despite this, temperate populations appear to show a different trend, with the biomass of this alga generally reaching a maximum during the summer (Friedlander \& Zelikovitch 1984; Aziza et al. 2008). Reis \& Yoneshigue-Valentin (2000) and Caires et al. (2013b) reported the presence of cystocarpic plants in "musciformis" only during the summer. Wallner et al. (1992) interpreted this as a response by the alga to improved light conditions. Despite of the biomass of female gametophytes showed no correlation with insolation, in the present study, we observed a positive correlation between both (female and male) gametophytes biomass with air temperature, and a negative correlation between with relative humidity, indicating that these conditions (usually observed in the Brazilian summer) could be related to the induction of fertilization and consequent development of cystocarps.

We observed significantly shorter thalli in June 2014, which coincided with the highest values of accumulated precipitation and humidity, and low values of air temperature and insolation. These factors, in conjunction with the strong waves observed at the collection site, could have contributed to thallus fragmentation (Reis \& Yoneshigue-Valentin 2000; Kong \& Ang Jr. 2004), and hence to the decreased lengths of thalli observed. The lengths of the thalli of tetrasporophytes and female gametophytes were not correlated with any of the environment variables recorded. Despite this, the lengths of male gametophytes were positively correlated with air temperature and insolation, and negatively correlated with precipitation and humidity, confirming that the optimal conditions for the development of this stage occurred during the dry season. Cecere et al. (2000) postulated that gametophytes are ephemeral; therefore, they could die soon after reproduction or become reproductive when still so small as to be undetected. Our findings suggested that, at least for the studied population of the "nigrescens" variant of Hypnea pseudomusciformis, this is not true, since tetrasporophytes and gametophytes had similar thallus heights. Nauer et al. (2017a) demonstrated in vitro that "musciformis" has a higher growth rate than "nigrescens", which could explain some of the differences observed and should be evaluated in the field.

Our results provide important data on the reproductive biology of a neglected intraspecific taxon, and provide evidence of the potential influence of the environmental variables we analyzed on its phenology. We have shown that the variant "nigrescens" exhibits remarkable differences in its phenology from the "musciformis" variant, especially regarding the expression of its sexual phases. Despite being recently combined into a single genetic species together with the "valentiae" variant (Hypnea pseudomusciformis), these taxa appear to present not only morphological differences, but also behavioural, developmental, and ecological differences from one another. Recognizing the factors that determine all of these differences remains a 


\section{Priscila Barreto de Jesus, Edilene Maria dos Santos Pestana, Helen Michelle de Jesus Affe, et al.}

major challenge to the resolution of these infraspecific relationships, which needs to be investigated through further research, especially since the morphological varieties are not yet formally proposed taxa.

\section{Acknowledgements}

This study was supported by the Conselho Nacional de Desenvolvimento Científico e Tecnológico - CNPq (UNIVERSAL 477614/2013-2) and the Fundação de Amparo à Pesquisa do Estado da Bahia - FAPESB (PRONEM T.O. PNE. 0020/2011). PBJ acknowledges Ph.D. scholarships from CNPq and EMSP acknowledges scholarships from CNPq and FAPESB through Programa Institucional de Bolsas de Iniciação Científica - PIBIC. JMCN acknowledges CNPq for a Productivity Scholarship in Research (307368/2015-7).

\section{References}

Aziza M, Givernaud T, Chikhaoui-Khay M, Bennasser L. 2008. Seasonal variation of the growth, chemical composition and carrageenan extracted from Hypnea musciformis (Wulfen) Lamouroux harvested along the Atlantic coast of Morocco. Scientific Research 2: 509-514.

Bitencourt FS, Figueiredo JG, Mota MRL, et al. 2008. Antinociceptive and anti-inflammatory effects of a mucinbinding agglutinin isolated from the red marine alga Hypnea cervicornis. Naunyn Schmiedeberg's Archives of Pharmacology 377: 139-148.

Caires TA, Costa IO, Jesus PB, Matos MRB, Pereira-Filho GH, Nunes JMC. 2013a. Evaluation of the stocks of Hypnea musciformis (Rhodophyta: Gigartinales) on two beaches in Bahia, Brazil. Brazilian Journal of Oceanography 61: 65-71.

Caires TA, Costa IO, Matos MRB, Lyra GM, Nunes JMC. 2013b. Phenological studies in populations of Hypnea musciformis (Rhodophyta: Gigartinales) in a tropical region of Brazil. Brazilian Journal of Oceanography 36: 135-140.

Cecere E, Saracino OD, Fanelli M, Petrocelli A. 2000. Phenology of two Acanthophora najadiformis (Rhodophyta, Ceramiales) populations in the Ionian Sea (Mediterranean Sea). Botanica Marina 43: 109-117.

Dobzhansky T. 1950. Mendelian populations and their evolution. The American Naturalist 84: 401-418.

Espinoza-Avalos JE. 2005. Fenología de macroalgas marinas. Hidrobiológica 15: 109-122.

Faccini AL, Berchez F. 2000. Management of natural beds and standing stock evaluation of Hypnea musciformis (Gigartinales, Rhodophyta) in South-Eastern Brazil. Journal of Applied Phycology 12: 101-103.

Forrest J, Miller-Rushing AJ. 2010. Toward a synthetic understanding of the role of phenology in ecology and evolution. Philosophical Transactions of the Royal Society B 365: 3101-3112.

Friedlander M, Zelikovitch N. 1984. Growth rates, phycocolloid yield and quality of the red seaweeds, Gracilaria sp., Pterocladia capillacea, Hypnea musciformis, and Hypnea cornuta, in field studies in Israel. Aquaculture 40: 57-66.

Guimarães SMPB. 2006. Checklist of Rhodophyta from the State of Espírito Santo. Boletim do Instituto de Botânica 17: 143-194

Guist Jr. GG, Dawes CJ, Castle JR. 1982. Mariculture of the red seaweed, Hypnea musciformis. Aquaculture 28: 375-384.

Jesus PB. 2012. O gênero Hypnea J.V. Lamouroux (Gigartinales, Rhodophyta) no litoral do estado da Bahia, Brasil: aspectos morfológicos e anatômicos. MSc Thesis, Universidade Estadual de Feira de Santana, Feira de Santana.

Jesus PB. 2016. Estudos biossistemáticos em espécies do gênero Hypnea J.V. Lamouroux (Gigartinales, Rhodophyta). PhD Thesis, Universidade Estadual de Feira de Santana, Feira de Santana.
Jesus PB, Guimarães SMPB, Nunes JMC. 2013a. Hypnea platyclada, a new species of red alga (Rhodophyta, Cystocloniaceae) from Brazil. Phytotaxa 85: 26-34.

Jesus PB, Nauer F, Lyra GM, et al. 2016. Species delimitation and phylogenetic analyses of some cosmopolitan species of Hypnea (Rhodophyta) reveal synonyms and misapplied names to H. cervicornis, including a new species from Brazil. Journal of Phycology 52: 774-792.

Jesus PB, Schnadelbach AS, Nunes JMC. 2013b. O gênero Hypnea (Cystocloniaceae, Rhodophyta) no litoral do estado da Bahia, Brasil. Sitientibus Série Ciências Biológicas 13: 1-21.

Jesus PB, Schnadelbach AS, Nunes JMC. 2014. O gênero Hypnea J.V. Lamouroux no litoral do estado da Bahia, Brasil: distribuição, aspectos morfológicos e anatômicos. Riga, Novas Edições Acadêmicas.

Jesus PB, Silva MS, Lyra GM, Nunes JMC, Schnadelbach AS. 2015. Extension of the distribution range of Hypnea stellulifera (Cystocloniaceae, Rhodophyta) to the South Atlantic: Morphological and molecular evidence. Aquatic Botany 123: 26-36.

Knutsen SH, Murano E, Damato M, Toffanin R, Rizzo R, Paoletti S. 1995. Modified procedures for extraction and analysis of carrageenans applied to the red alga Hypnea musciformis (Wulfen) Lamouroux. Journal of Applied Phycology 7: 12.

Kong CSL, Ang Jr. PO. 2004. Seasonal occurrence and reproduction of Hypnea charoides (Rhodophyta) in Tung Ping Chau, N.T., Hong Kong SAR, China. Hydrobiologia 512: 63-78.

Leão ZMAN, Kikuchi RKP, Oliveira MDM, Vasconcelos V. 2010. Status of Eastern Brazilian coral reefs in time of climate changes. Pan-American Journal of Aquatic Sciences 5: 224-235.

Lyra GM, Santos ACC, Nunes JMC. 2007. Rodofíceas marinhas bentônicas das praias da Concha e Engenhoca, Município de Itacaré - Bahia, Brasil. Acta Botanica Malacitana 32: 234-240.

Masuda M, Yamagishi Y, Chiang Y-M, Lewmanomont K, Bangmei X. 1997. Overview of Hypnea (Rhodophyta, Hypneaceae) In: Abbott IA. (ed.) Taxonomy of economic seaweeds with reference to some Pacific species. Vol. VI. California, California Sea Grant College System. p. 127-133.

Mathieson AC. 1989. Phenological patterns of New England seaweeds. Botanica Marina 32: 419-438.

Mayr E. 1942. Systematics and the origin of species. New York, Columbia University Press.

Melo VMM, Medeiros DA, Rios FJB, Castelar LIM, Carvalho ADFU. 1997. Antifungal properties of proteins (agglutinins) from the red alga Hypnea musciformis (Wulfen) Lamouroux. Botanica Marina 40: 281284.

Mouradi A, Chikhaoui M, Fekhaoui M, Bennasser L, Chiadmi N, Thierry G. 2008. Croissance et capacité reproductive d'Hypnea musciformis (Rhodophyceae, Gigartinale) de la côte atlantique marocaine. Afrique Science 4: 99-124.

Mshigeni KE. 1976a. A note on the fate of tetrasporangial stichidia in Hypnea Lamouroux after spore release. Botanica Marina 19: 313-315.

Mshigeni KE. 1976b. Development studies in Hypnea cervicornis J. Agardh and Hypnea chordacea Kützing: spore germination. Botanica Marina 19: 217-221.

Mshigeni KE. 1976c. Studies on the reproduction of selected species of Hypnea (Rhodophyta, Gigartinales) from Hawaii. Botanica Marina 19: 341-346.

Mshigeni KE. 1977. Seasonal changes in the standing crop of three Hypnea species (Rhodophyta, Gigartinales) in Hawaii. Botanica Marina 20: 303-306.

Najam R, Ahmed SP, Azhar I. 2010. Pharmacological Activities of Hypnea musciformis. African Journal of Biomedical Research 13: 69-74.

Nauer F, Ayres LM, Plastino EM, Oliveira MC. 2017a. Life history of two morphological variants of Hypnea pseudomusciformis (Gigartinales, Rodophyta). Phycologia 56: 134.

Nauer F, Cassano V, Oliveira MC. 2015. Description of Hypnea pseudomusciformis sp. nov., a new species based on molecular and morphological analyses, in the context of the H. musciformis complex (Gigartinales, Rhodophyta). Journal of Applied Phycology 27: 24052417. 


\section{Reproductive morphology and phenological aspects of one morphological variant of Hypnea pseudomusciformis (Gigartinales, Rhodophyta)}

Nauer F, Cassano V, Plastino EM, Oliveira MC. 2017b. Species dilemma: a case study on Hypnea musciformis (Gigartinales, Rhodophyta). Phycologia 56: 135.

Nunes JMC. 2005. Rodofíceas marinhas bentônicas do estado da Bahia, Brasil. PhD Thesis, Universidade de São Paulo, São Paulo.

Nunes JMC. 2010. Taxonomia morfológica: metodologia de trabalho. In: Pedrini AG. (ed.) Macroalgas, uma introdução à taxonomia. Rio de Janeiro, Technical Books. p. 54-70.

R Core Team 2018. R: A language and environment for statistical computing. Vienna, R Foundation for Statistical Computing. https: //www.R-project.org/. 15 Jan. 2018.

Rangaiah GS, Rao MU. 1983. Seasonal growth, reproduction and spore shedding in Hypnea valentiae (Tun.) Mont. Proceedings of the Indian Academy of Sciences Plant Science Section B 92: 473-482.

Rao KR. 1970. Studies on growth cycle and phycocolloid content in Hypnea musciformis (Wulf) Lamour. Botanica Marina 13: 163-165.

Rao KR. 1977. Studies on Indian Hypneaceae II. Reproductive capacity in the two species of Hypnea over the different seasons. Botanica Marina 20: 33-39.

Reis RP, Yoneshigue-Valentin Y. 1998. Variação espaço temporal de populações de Hypnea musciformis (Rhodophyta, Gigartinales) na Baía de Sepetiba e Armação dos Búzios, Rio de Janeiro, Brasil. Acta Botanica Brasilica 12: 465-483.

Reis RP, Yoneshigue-Valentin Y. 2000. Phenology of Hypnea musciformis (Wulfen) Lamouroux (Rhodophyta, Gigartinales) in three populations from Rio de Janeiro State, Brazil. Botanica Marina 43: 299-304.

Reis RP, Yoneshigue-Valentin Y, Santos CP. 2008. Spatial and temporal variation of Hypnea musciformis carrageenan (Rhodophyta:
Gigartinales) from natural beds in Rio de Janeiro State, Brazil. Journal of Applied Phycology 20: 1-8.

Schenkman RPF. 1986. Cultura de Hypnea (Rodophyta) in vitro como subsídio para estudos morfológicos, reprodutivos e taxonômicos. $\mathrm{PhD}$ Thesis, Universidade de São Paulo, São Paulo.

Schenkman RPF. 1989. Hypnea musciformis (Rhodophyta): ecological influence on growth. Journal of Phycology 25: 192-196.

Selvan CT, Kannan L. 1990. Effects of manures from seaweeds on rice (Oryzia sativa L.). International Journal of Tropical Agriculture 8: 117-122.

Shameel M, Afaq-Husain S, Zarina A. 2012. Structure, growth and reproduction of red alga, Hypnea pannosa, from the Karachi coast of Pakistan. International Journal on Algae 14: 398-405.

Smith JE, Hunter CL, Smith CM. 2002. Distribution and reproductive characteristics of nonindigenous and invasive marine algae in the Hawaiian Islands. Pacific Science 56: 299-315.

Wallner M, Lobo S, Boccanera N, Silva EM. 1992. Biomass, carrageenan yield and reproductive state of Hypnea musciformis (Rhodophyta: Gigartinales) under natural and experimental cultivated conditions. Aquaculture \& Fishering Management 23: 443-451.

Wreede RE. 1985. Destructive (harvest) sampling. In: Littler MM, Littler DS. (eds.) Handbook of phycological methods ecological field methods: Macroalgae. Cambridge, Cambridge University Press. p. 147-160

Wright S. 1940. The statistical consequences of Mendelian heredity in relation to speciation. In: Huxley J. (ed.) The new systematics. Oxford, Oxford University Press. p. 161-183. 